九州大学学術情報リポジトリ

Kyushu University Institutional Repository

Effects of Dam Age, Lamb Gender, and Singleton or Twin Status on Bodyweight and Chest Measurements of Malya Lambs in Middle Anatolia, Turkey

Çi lek, Süleyman

Department of Animal Breeding, Veterinary Faculty, Kırıkkale University

Gotoh, Takafumi

Kuju Agricultural Research Center, Faculty of Agriculture, Kyushu University

https://doi.org/10.5109/1526397

出版情報：九州大学大学院農学研究院紀要. 60 (2)，pp.371-375，2015-09-18. Faculty of Agriculture, Kyushu University

バージョン：

権利関係 : 


\title{
Effects of Dam Age, Lamb Gender, and Singleton or Twin Status on Bodyweight and Chest Measurements of Malya Lambs in Middle Anatolia, Turkey
}

\section{Süleyman ÇILEK ${ }^{1}$ and Takafumi GOTOH}

\author{
Kuju Agricultural Research Center, Faculty of Agriculture, \\ Kyushu University, Kuju, Oita, 878-0201, Japan \\ (Received May 18, 2015 and accepted May 19, 2015)
}

\begin{abstract}
We investigated the effects of dam age, lamb gender, and singleton or twin status on lamb chest measurements and body weight in Malya lambs in Middle Anatolia, Turkey. Data were obtained from 302 lambs in an elite Malya sheep flock. Bodyweight, chest circumference, chest depth, chest length, and chest width were recorded. The least square means method was used to determine factors that significantly affected lamb body weight and chest measurements. The general linear model in the Minitab packet program was used to test the effects of variables on body weight and chest measurements. Dam age did not significantly affect lamb bodyweight or chest measurements during the first year of life, except for chest circumference and chest depth. Male lambs were significantly larger in bodyweight and chest measurements than females at the age of 12 months $(p<0.001$ for all parameters). Singleton lambs were significantly larger in bodyweight and chest-related parameters than twins until 4 months of age, but this effect was only significant at 12 months of age for chest width. It is suggested that there might be compensatory growth in twin lambs after weaning. If farmers are able to ensure twin lamb survival until weaning age, they can expect compensatory growth by 12 months of age.
\end{abstract}

Key words: sheep, Malya, thoracic body measurements, growth, body weight

\section{INTRODUCTION}

To improve low meat and wool yield, Turkey's fattailed Akkaraman a breed of domestic sheep was mated with Deutsches Merinofleischschaf (German Whiteheaded Mutton) rams using a combination breeding system in 1959 to obtain the Malya breed with semi-fat tails. The Merino traits of a long thin tail, high meat yield, and rapid development were combined with the characteristics of fat-tailed Akkaraman sheep, including the ability to adapt to steep terrain, harsh winters, and poor feeding conditions. The resulting Malya sheep genotype is 11/16 Akkaraman, and 5/16 Deutsches Merinofleischschaf. Since 1960s, Malya sheep have been bred as a closed flock solely in the Malya State Farm of Turkey (Düzgüneş and Pekel, 1966; Anomious, 2006; Atasever, 2006). Following the creation of the Malya sheep breed, only two studies have been conducted on the growth traits of Malya lambs (Düzgüneş and Pekel, 1966; Çolakoğlu and Özbeyaz, 1999).

Our previous study reported the effect of dam age, birth type (singleton or twin), and gender on some body frame size measurements and growth in Malya lambs (Çilek and Gotoh, 2014). Dam age did not significantly affect body size parameters during the first year of life, except for rump length and front cannon bone circumference. Male lambs were significantly larger between birth and 12 months of age than females in body length, wither height, back height, rump height, rump length, rump width, and front cannon bone circumstance.

Department of Animal Breeding, Veterinary Faculty, Kirıkkale University, 71450, Kırıkkale, Turkey

* Corresponding author: Takafumi GOTOH (E-mail: gotoh@ farm.kyushu-u.ac.jp )
Singleton lambs were significantly larger than twins for all of the above size parameters until 6 months of age, but this effect was not significant after 6 months of age; this suggests that there might be compensatory growth in twin lambs after weaning.

The purpose of the current study was to determine the mean bodyweight and thoracic measurements (chest circumference, chest depth, chest length, and chest width) of Malya lambs monthly from birth until the yearling stage.

\section{MATERIALS AND METHODS}

This study was conducted between February 2012 and February 2013 on an elite flock of Malya sheep bred on the Malya State Farm that is connected to the General Directorate of Agricultural Enterprises. Malya State Farm is located $27 \mathrm{~km}$ north-east of the city of Kırşehir in Middle Anatolia region of Turkey; it has a steep terrain and is very suitable for sheep breeding.

We used the same lambs as in our previous study (Çilek and Gotoh, 2014). The number of animals were also as described in the previous study (Çilek and Gotoh, 2014); 31-101 animals were examined for analysis of effect of dam age on growth parameters, 61-152 animals were examined for analysis of effect of singleton or twin status on growth parameters, and 20-161 animals were examined for analysis of effect of lamb gender on growth parameters. Animals were habituated and started on lamb starter feed at 15 days of age for subsequent intensive feeding. They were nursed by their dams twice per day until weaning at 4 months of age. At 40 days of age, $250 \mathrm{~g} /$ day lamb starter feed was added to their diet; this was subsequently increased to $300 \mathrm{~g} /$ day by 4 months of age. After weaning, the animals grazed on pasture and 
were fed approximately $800 \mathrm{~g} /$ day of additional feed.

More male lambs than females were sold to slaughter after feeding for 2-3 months post-weaning. Therefore, this study was continued up to 1 year of age with the majority of the female lambs remaining as stud on this farm.

Bodyweight and chest measurements of 302 lambs from Malya ewes that lambed in February 2012 were measured by the same person. Bodyweight, chest length, chest depth, chest width, and chest circumference were measured monthly until weaning, and then at 6 months, 9 months, and 1 year of age; that is, the measurements were taken at birth, and on the $30^{\text {th }}, 60^{\text {th }}, 90^{\text {th }}, 120^{\text {th }}, 180^{\text {th }}$, $270^{\text {th }}$ and $365^{\text {th }}$ day after birth.

Table 1. Comparison of bodyweight, chest circumference, chest depth, chest length, and chest width among Malya lambs from different aged dams.

\begin{tabular}{|c|c|c|c|c|c|c|}
\hline dam age & 2 & 3 & 4 & 5 & means & $\mathrm{P}$ value \\
\hline \multicolumn{7}{|c|}{ Body weigth (kg) } \\
\hline 0 & 3.65 & 4.99 & 4.92 & 4.81 & 4.80 & 0.243 \\
\hline 1 & $12.05^{c}$ & $12.89^{\text {a }}$ & $12.40^{\mathrm{bc}}$ & $12.46^{\mathrm{b}}$ & 12.44 & 0.049 \\
\hline 2 & 17.74 & 18.81 & 18.29 & 18.03 & 18.22 & 0.203 \\
\hline 3 & 23.57 & 24.58 & 23.94 & 24.29 & 24.09 & 0.541 \\
\hline 4 & 32.20 & 32.85 & 31.81 & 32.27 & 32.28 & 0.704 \\
\hline 6 & 39.45 & 39.49 & 37.90 & 39.91 & 39.19 & 0.18 \\
\hline 9 & $49.99^{\text {a }}$ & $46.65^{\mathrm{b}}$ & $46.67^{\mathrm{b}}$ & $47.61^{\mathrm{ab}}$ & 47.73 & 0.021 \\
\hline 12 & 55.30 & 52.73 & 52.21 & 53.05 & 53.32 & 0.063 \\
\hline \multicolumn{7}{|c|}{ Chest circumference $(\mathrm{cm})$} \\
\hline 0 & 35.68 & 36.05 & 36.32 & 35.69 & 35.93 & 0.214 \\
\hline 1 & 50.46 & 51.79 & 51.15 & 50.81 & 51.05 & 0.054 \\
\hline 2 & 57.68 & 58.52 & 58.20 & 57.71 & 58.03 & 0.42 \\
\hline 3 & 62.80 & 63.78 & 63.29 & 63.31 & 63.29 & 0.521 \\
\hline 4 & 69.88 & 70.58 & 69.64 & 69.60 & 69.92 & 0.442 \\
\hline 6 & 75.63 & 75.68 & 74.80 & 75.23 & 75.34 & 0.485 \\
\hline 9 & $82.00^{a}$ & $80.77^{\text {ab }}$ & $80.10^{\mathrm{b}}$ & $80.25^{b}$ & 80.78 & 0.049 \\
\hline 12 & $85.26{ }^{\text {a }}$ & 83.71 ab & 83.72 ab & $83.20^{b}$ & 83.97 & 0.039 \\
\hline \multicolumn{7}{|c|}{ Chest depth (cm) } \\
\hline 0 & $15.14^{\mathrm{b}}$ & $15.38^{\mathrm{ab}}$ & $15.58^{\text {a }}$ & $15.31^{\mathrm{ab}}$ & 15.35 & 0.023 \\
\hline 1 & 20.37 & 20.80 & 20.66 & 20.62 & 20.61 & 0.233 \\
\hline 2 & 22.71 & 22.95 & 23.13 & 23.16 & 22.99 & 0.287 \\
\hline 3 & 25.05 & 25.52 & 25.44 & 25.69 & 25.43 & 0.152 \\
\hline 4 & 28.40 & 28.47 & 28.62 & 28.18 & 28.42 & 0.57 \\
\hline 6 & 32.01 & 32.03 & 31.66 & 32.08 & 31.95 & 0.533 \\
\hline 9 & 34.81 & 34.26 & 34.02 & 34.20 & 34.32 & 0.068 \\
\hline 12 & 35.84 a & $35.14^{\mathrm{ab}}$ & $34.74^{\mathrm{b}}$ & $35.27 \mathrm{ab}$ & 35.25 & 0.024 \\
\hline \multicolumn{7}{|c|}{ Chest length $(\mathrm{cm})$} \\
\hline 0 & $14.08^{b}$ & $14.24^{\mathrm{ab}}$ & $14.57^{\text {a }}$ & $14.53^{\mathrm{a}}$ & 14.35 & 0.03 \\
\hline 1 & 19.30 & 19.84 & 19.86 & 19.73 & 19.68 & 0.065 \\
\hline 2 & 21.74 & 21.89 & 22.07 & 21.39 & 21.77 & 0.16 \\
\hline 3 & $23.91^{\mathrm{b}}$ & $24.49^{\mathrm{ab}}$ & $24.60^{\mathrm{a}}$ & $25.12^{a}$ & 24.53 & 0.003 \\
\hline 4 & 27.58 & 27.46 & 27.68 & 27.56 & 27.57 & 0.946 \\
\hline 6 & 29.89 & 29.57 & 29.47 & 30.02 & 29.74 & 0.38 \\
\hline 9 & $33.15^{\mathrm{a}}$ & $32.19^{\mathrm{b}}$ & $32.22^{\mathrm{b}}$ & $33.00^{\mathrm{a}}$ & 32.64 & 0.021 \\
\hline 12 & 34.29 & 33.45 & 33.51 & 34.08 & 33.83 & 0.082 \\
\hline \multicolumn{7}{|c|}{ Chest width $(\mathrm{cm})$} \\
\hline 0 & 9.45 & 9.53 & 9.60 & 9.44 & 9.50 & 0.58 \\
\hline 1 & 13.53 & 13.69 & 13.70 & 13.70 & 13.65 & 0.574 \\
\hline 2 & 15.50 & 15.51 & 15.38 & 15.31 & 15.42 & 0.683 \\
\hline 3 & 15.84 & 16.19 & 15.93 & 16.35 & 16.08 & 0.098 \\
\hline 4 & 17.77 & 17.98 & 17.77 & 17.75 & 17.82 & 0.713 \\
\hline 6 & 18.91 & 19.20 & 18.77 & 18.90 & 18.95 & 0.434 \\
\hline 9 & 21.17 & 20.72 & 21.09 & 20.88 & 20.97 & 0.361 \\
\hline 12 & 21.59 & 21.43 & 20.98 & 21.28 & 21.32 & 0.220 \\
\hline
\end{tabular}

Data are presented as the means. ${ }^{\mathrm{a}, \mathrm{b}, \mathrm{c}}$ denote significant differences $(\mathrm{P}<0.05)$. 
To measure bodyweight, a small animal scale with a precision of 100 grams and a capacity of $300 \mathrm{~kg}$ was used. Bodyweights were measured when lambs were hungry in the early hours of morning. Chest circumference was a circumferential measure taken around the chest from a little behind the front legs (Bıyıkoğlu, 2009) (Figure 1). Chest depth was measured as vertical distance from withers to sternum (Bıyıkoğlu, 2009). Chest width was measured as the distance between the left and right caput humeri (Koncagül et al., 2012) (Figure 1). Chest length was measured as the distance from the acromion of the scapula to the last thoracic rib, as it is difficult to feel the first rib in live animals (Çalışlar et al., 1996). See Figure 1 for chest measurement sites.

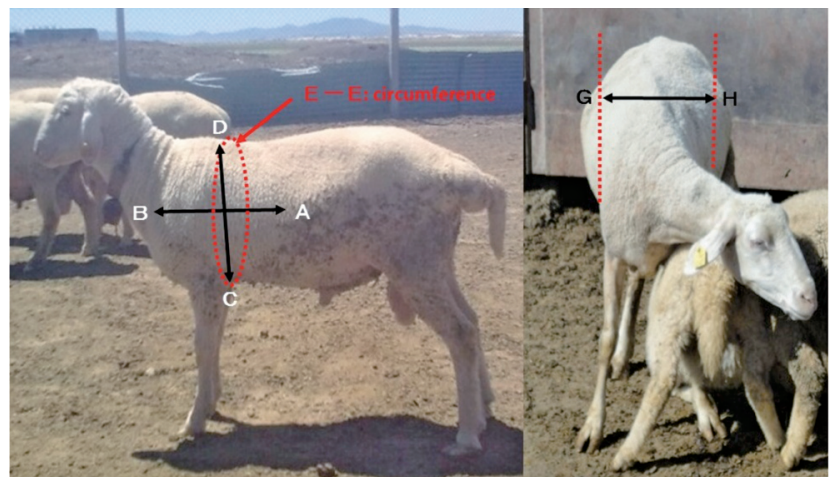

Fig. 1. Position of chest measurements used in this study. A-B: chest length. E-E: chest circumference. D-C: chest depth. G-H: chest width (Photographs taken by Dr. Süleyman ÇİLEK)

As sheep aged 5 years and older had reformed in this farm, dam age groups were limited to four age groups: 2 years old, 3 years old, 4 years old, and 5 years and older.

Least square values were calculated for body measurements of Malya lambs at birth and on the $30^{\text {th }}, 60^{\text {th }}$, $90^{\text {th }}, 120^{\text {th }}, 180^{\text {th }}, 270^{\text {th }}$ and $365^{\text {th }}$ day after birth. The general linear model using the Minitab program (Minitab, 1998) was used to investigate the effects of dam age, lamb gender, and type of birth (singleton or twin) on the abovementioned measurements. Duncan's multiple range tests were used for multiple comparisons in important subgroups (Duncan 1955).

\section{RESULTS AND DISCUSSION}

\section{Effect of dam age on bodyweight and chest meas- urements}

Bodyweight of offspring at 1 month of age was significantly larger in the lambs from 3-year-old dams than in those from dams of other ages ( $p=0.049$; Table 1$)$. Bodyweight of offspring at 9 months of age was also significantly larger in the lambs from 2-year-old dams than in those from 3- and 4-year-old dams ( $p=0.021$; Table 1). However, bodyweight of offspring at other ages did not show significant differences among different age groups of dams.

The mean chest circumference of offspring at 9 and 12 months of age was significantly larger in the lambs from 2-year-old dams than in those from 4-year-old dams and dams 5 years and older $(p=0.049, p=0.039$, respectively; Table 1 ). There were no significant differences in mean chest circumference of offspring at 0-6 months of age among different dam age groups.

The mean chest depth of offspring at birth was significantly larger in the lambs from 4-year-old dams than in those from 2-year-old dams ( $p=0.023$; Table 1$)$. The mean chest depth at 12 months of age was significantly larger in the lambs from 2-year-old dams than in those from 4-year-old dams ( $p=0.024$; Table 1$)$. There were no significant differences in mean chest depth of offspring at other ages among different dam age groups.

The mean chest length of offspring at birth and 3 months of age was significantly larger in the lambs from 4- and 5-year-old dams than in those from 2-year-old dams ( $p=0.03, p=0.003$, respectively; Table 1$)$. The mean chest length at 9 months of age was significantly larger in the lambs from 2- and 5-year-old dams than in those from $3-$ and 4-year-old dams ( $p=0.021$; Table 1 ). There were no significant differences in mean chest length at 1, 2, 4, 6, and 12 months of age among lambs from different dam age groups.

The mean chest width of offspring was not significantly different at any age among lambs from different dam age groups.

Based on these results, we suggest that dam age from 2 to 5 years does not strongly affect the first year growth performance of Malya lambs as there was no significant difference in bodyweight of offspring at 12 months of age among lambs born to dams of different ages. Chest circumference and chest depth were larger in the lambs from 2-year-old dams.

\section{Effect of singleton or twin status on bodyweight and chest measurements}

The mean body weight at $0,1,2,3,4$, and 9 months of age was significantly larger in singleton lambs than twins $(p<0.001$ until 4 months of age, $p=0.006$ at 9 months of age; Table 2). There were no significant differences between the mean bodyweight of singletons and twins at 6 and 12 months of age.

The mean chest circumference at $0,1,2,3,4$, and 6 months of age was significantly larger in singleton lambs than twins $(p<0.001$ until 4 months of age, $p<0.03$ at 6 months of age; Table 2). There was no significant difference between the mean chest circumference of singletons and twins at 9 and 12 months of age.

The mean chest depth at 0,1,3 and 4 months of age was significantly larger in singleton lambs than twins $(p<0.001$ at 0,1 and 4 months of age, $p=0.021$ at 3 months of age; Table 2). There was no significant difference between the mean chest depth of singletons and twins at 2, 6, 9 and 12 months of age.

The mean chest length at $0,1,2,3$ and 4 months of age was significantly larger in singleton lambs than twins $(p<0.001$ at $0,1,2$ and 4 months of age, $p=0.006$ at 3 months of age; Table 2). There was no significant difference in mean chest length between singletons and twins at 6,9 and 12 months of age. 
Table 2. Comparison of bodyweight, chest circumference, chest depth, chest length, and chest width between birth type (singleton or twin) or gender in Malya lambs.

\begin{tabular}{|c|c|c|c|c|c|c|}
\hline \multirow{2}{*}{ traits } & \multicolumn{3}{|c|}{ birth type } & \multicolumn{3}{|c|}{ gender } \\
\hline & singleton & twin & $\mathrm{P}$ value & male & female & $\mathrm{P}$ value \\
\hline \multicolumn{7}{|c|}{$\begin{array}{c}\text { Body weigth }(\boldsymbol{k g}) \\
\text { month of age }\end{array}$} \\
\hline 0 & $5.45^{\mathrm{x}}$ & $3.74^{\mathrm{Y}}$ & $<0.001$ & $5.09^{x}$ & $4.10^{\mathrm{Y}}$ & $<0.001$ \\
\hline 1 & $13.51^{\mathrm{x}}$ & $11.37^{\mathrm{Y}}$ & $<0.001$ & $12.83^{\mathrm{A}}$ & $12.05^{\mathrm{B}}$ & 0.001 \\
\hline 2 & $19.65^{\mathrm{x}}$ & $16.79^{Y}$ & $<0.001$ & $18.74^{\mathrm{A}}$ & $17.69^{\text {в }}$ & 0.004 \\
\hline 3 & $25.28^{x}$ & $22.91^{\mathrm{Y}}$ & $<0.001$ & $24.95^{\mathrm{A}}$ & $23.24^{\text {в }}$ & 0.001 \\
\hline 4 & $34.37^{\mathrm{x}}$ & $30.19^{\mathrm{Y}}$ & $<0.001$ & $34.21^{\mathrm{x}}$ & $30.36^{\mathrm{Y}}$ & $<0.001$ \\
\hline 6 & 39.67 & 38.71 & 0.18 & $42.54^{x}$ & $35.85^{\mathrm{Y}}$ & $<0.001$ \\
\hline 9 & $49.08^{x}$ & $46.38^{y}$ & 0.006 & $53.10^{x}$ & $42.36^{\mathrm{Y}}$ & $<0.001$ \\
\hline 12 & 53.71 & 52.94 & 0.434 & $62.75^{x}$ & $43.89^{\mathrm{Y}}$ & $<0.001$ \\
\hline \multicolumn{7}{|c|}{$\begin{array}{l}\text { Chest circumference }(\mathbf{c m}) \\
\text { month of age }\end{array}$} \\
\hline 0 & $36.66^{\mathrm{x}}$ & $35.21^{\mathrm{Y}}$ & $<0.001$ & $36.25^{a}$ & $35.62^{b}$ & 0.024 \\
\hline 1 & $51.86^{x}$ & $50.24^{\mathrm{Y}}$ & $<0.001$ & 51.32 & 50.79 & 0.136 \\
\hline 2 & $59.36^{\mathrm{x}}$ & $56.69^{\mathrm{Y}}$ & $<0.001$ & 58.30 & 57.76 & 0.184 \\
\hline 3 & $64.17^{\mathrm{x}}$ & $62.42^{Y}$ & $<0.001$ & $63.82^{a}$ & $62.77^{\text {b }}$ & 0.028 \\
\hline 4 & $71.14^{x}$ & $68.71^{\mathrm{Y}}$ & $<0.001$ & $70.68^{A}$ & $69.17^{\text {в }}$ & 0.001 \\
\hline 6 & $75.86^{\mathrm{a}}$ & $74.81^{\mathrm{b}}$ & 0.03 & $76.75^{\mathrm{x}}$ & $73.93^{Y}$ & $<0.001$ \\
\hline 9 & 80.79 & 80.77 & 0.973 & $82.91^{\mathrm{x}}$ & $78.66^{Y}$ & $<0.001$ \\
\hline 12 & 84.53 & 83.42 & 0.064 & $87.40^{\mathrm{x}}$ & $80.55^{\mathrm{Y}}$ & $<0.001$ \\
\hline \multicolumn{7}{|c|}{ Chest depth (cm) } \\
\hline 0 & $15.60^{x}$ & $15.11^{\mathrm{Y}}$ & $<0.001$ & $15.51^{\mathrm{A}}$ & $15.20^{\text {в }}$ & 0.004 \\
\hline 1 & $20.92^{\mathrm{x}}$ & $20.31^{Y}$ & $<0.001$ & $20.84^{\mathrm{A}}$ & $20.39^{\text {в }}$ & 0.004 \\
\hline 2 & 22.92 & 23.05 & 0.515 & $23.28^{\mathrm{A}}$ & $22.69^{\text {в }}$ & 0.003 \\
\hline 3 & $25.68^{a}$ & $25.17^{\mathrm{b}}$ & 0.021 & $25.66^{a}$ & $25.19^{b}$ & 0.032 \\
\hline 4 & $29.15^{\mathrm{x}}$ & $27.68^{Y}$ & $<0.001$ & $29.03^{x}$ & $27.80^{\mathrm{Y}}$ & $<0.001$ \\
\hline 6 & 32.04 & 31.85 & 0.427 & $32.45^{\mathrm{x}}$ & $31.45^{\mathrm{Y}}$ & $<0.001$ \\
\hline 9 & 34.47 & 34.18 & 0.252 & $35.20^{\mathrm{x}}$ & $33.45^{\mathrm{Y}}$ & $<0.001$ \\
\hline 12 & 33.60 & 34.07 & 0.096 & $35.50^{x}$ & $32.17^{\mathrm{Y}}$ & $<0.001$ \\
\hline \multicolumn{7}{|c|}{ Chest length (cm) } \\
\hline 0 & $15.03^{x}$ & $13.67^{\mathrm{Y}}$ & $<0.001$ & 14.47 & 14.24 & 0.117 \\
\hline 1 & $20.16^{x}$ & $19.20^{\mathrm{Y}}$ & $<0.001$ & 19.83 & 19.54 & 0.113 \\
\hline 2 & $22.33^{x}$ & $21.21^{\mathrm{Y}}$ & $<0.001$ & 21.93 & 21.61 & 0.122 \\
\hline 3 & $24.86^{\mathrm{x}}$ & $24.20^{y}$ & 0.006 & 24.73 & 24.33 & 0.085 \\
\hline 4 & $28.55^{x}$ & $26.59^{\mathrm{Y}}$ & $<0.001$ & 27.77 & 27.37 & 0.113 \\
\hline 6 & 29.82 & 29.65 & 0.497 & $30.27^{\mathrm{x}}$ & $29.20^{\mathrm{Y}}$ & $<0.001$ \\
\hline 9 & 32.78 & 32.51 & 0.355 & $34.30^{x}$ & $30.98^{\mathrm{Y}}$ & $<0.001$ \\
\hline 12 & 35.48 & 35.02 & 0.103 & $37.02^{x}$ & $33.48^{\mathrm{Y}}$ & $<0.001$ \\
\hline \multicolumn{7}{|c|}{$\begin{array}{c}\text { Chest width }(\mathbf{c m}) \\
\text { month of age }\end{array}$} \\
\hline 0 & $9.62^{\text {a }}$ & $9.39^{\mathrm{b}}$ & 0.01 & $9.65^{\mathrm{A}}$ & $9.36^{\text {в }}$ & 0.001 \\
\hline 1 & $14.07^{\mathrm{x}}$ & $13.24^{\mathrm{Y}}$ & $<0.001$ & $13.85^{\mathrm{A}}$ & $13.46^{\text {в }}$ & 0.001 \\
\hline 2 & $15.92^{\mathrm{x}}$ & $14.93^{\mathrm{Y}}$ & $<0.001$ & $15.71^{\mathrm{x}}$ & $15.14^{\mathrm{Y}}$ & $<0.001$ \\
\hline 3 & $16.34^{\mathrm{A}}$ & $15.81^{\text {в }}$ & 0.002 & $16.27^{\mathrm{a}}$ & $15.88^{b}$ & 0.018 \\
\hline 4 & $18.30^{\mathrm{x}}$ & $17.33^{\mathrm{Y}}$ & $<0.001$ & $18.26^{x}$ & $17.38^{Y}$ & $<0.001$ \\
\hline 6 & $19.15^{\mathrm{a}}$ & $18.74^{b}$ & 0.03 & $19.66^{\mathrm{x}}$ & $18.24^{\mathrm{Y}}$ & $<0.001$ \\
\hline 9 & $21.29^{\mathrm{A}}$ & $20.64^{\text {в }}$ & 0.003 & $22.04^{\mathrm{x}}$ & $19.90^{\mathrm{Y}}$ & $<0.001$ \\
\hline 12 & $21.67^{\mathrm{A}}$ & $20.98^{\text {в }}$ & 0.003 & $22.72^{x}$ & $19.93^{\mathrm{Y}}$ & $<0.001$ \\
\hline
\end{tabular}

Data are presented as the means. ${ }^{a, b}$ denotes a significant difference between singleton and twin or male and female $(p<0.05)$. ${ }^{A, B}$ denotes a significant difference between singleton and twin or male and female $(p<0.005) .{ }^{X Y}$ denotes a significant difference between singleton and twin or male and female $(p<0.01)$.

${ }_{x, y}$ denotes a significant difference between singleton and twin or male and female $(p<0.001)$. 
The mean chest width at all ages measured was significantly larger in singleton lambs than twins $(p=0.01$ at 0 months of age, $p<0.001$ at 1,2 , and 4 months of age, $p=0.002$ at 3 months of age, $p=0.03$ at 6 months of age, $p=0.003$ at 9 and 12 months of age; Table 2 ).

These results indicate that singleton or twin status strongly affected growth performance as measured by lamb bodyweight, chest circumference, chest depth, chest length, and chest width until 4 months of age. Almost all bodyweight and chest measurements were significantly larger in singleton lambs than in twins until approximately 4 months of age (Table 2); however, after 6 months of age these size differences disappeared. Only chest width was still significantly larger in singleton lambs than in twins until 12 months of age. However, bodyweight and size was similar between singleton and twin lambs at 12 months of age except for chest width.

\section{Effect of lamb gender on bodyweight and chest measurements}

Male lambs had significantly greater mean bodyweight, chest depth, and chest width from birth to 12 months of age compared with females (Table 2). Male lambs had significantly higher mean chest circumference than females at $0,3,4,6,9$ and 12 months of age $(p=$ 0.024 at 0 months, $p=0.028$ at 3 months, $p=0.001$ at 4 months, $p<0.001$ at 6,9 , and 12 months; Table 2). Males also had a significantly larger mean chest length than females at 6,9 , and 12 months of age $(p<0.001$ at all ages; Table 2). There were no significant differences in mean chest length between males and females at 0, 1, 2, 3 and 4 months of age.

These results clearly suggest that males have larger body sizes than females during the first year of life. After 6 months of age, bodyweight and all chest-related measurements accelerated in males relative to females.

In conclusion, combined with our previous research (Çilek and Gotoh, 2014), we have shown that lamb chest circumference, chest depth, rump length, and front cannon bone circumstance by 12 months of age are positively affected by dam age, with higher measurements found in lambs from younger dams. This means that lamb body type is affected by the age of the dam. Although there were significant effects on lamb bodyweight and chest-related measurements before weaning, only the effect of singleton or twin status on chest width was sig- nificant after weaning; hence, only chest width is affected by singleton or twin status. Finally, lamb bodyweight and all chest measurements at 12 months of age were significantly larger in males than in females.

\section{ACKNOWLEDGMENTS}

This research was supported by the Scientific Research Project Coordination Unit of Kırıkkale University (Project number 2011/38). The authors are grateful for assistance from the scientific Research Project Coordination Unit of Kırıkkale University. The author also wishes to thank his mother and father, Zahide and Ali Çilek, his dear housekeeper Mehmet Gevrek, shepherd Kaya Turan Kaya, and Veterinary Medicine expert Kadir Gökhan Ylldırım for their support.

\section{REFERENCES}

Anomious, 2006 Tarm işletmeleri genel müdürlüğ̈̈ (TIGEM) kayıtlar, Ankara

Atasever, H. 2006 Sağlıklı çiftlik hayvanları yetiştiriciliğ̣i, Türkiye'de çiftlik hayvanları yetiştiriciliği sı̆̆ır, at, koyun, domuz, kısım 1. Ciftlik hayvanları yetiştiriciliği, Yücel ofset matbaacılık Turizm San. Tic. Ltd. Şti. In "Keeping livestock healthy", ed. by N. B. Haynes, p. 436

Bıyıkoğlu, K. 2009 Genel zootekni, Atatürk Üniversitesi Yayınları No: $231,285-288$

Çalışlar, T., O. Kahvecioğlu and R. Mutuş 1996 Veteriner topografik anatomi, Medisan yayınları No: 22; pp. 11-110

Çilek, S. and T. Gotoh 2014 Effect of Age of Dams, Difference of Birth Type (Single or Twins) and Gender on Body Frame Size with Growth in Malya Lambs in Middle Anatolia in Turkey. J. Fac. Agr. Kyushu Univ., 59(2): 313-320

Çolakoğlu, N. and C. Özbeyaz 1999 Akkaraman ve Malya Koyunlarının Bazı Verim Özelliklerinin Karşılaştırılması Tr. J. Vet. Anim. Sci., 23: 351-360

Duncan, D. B. 1955 Multiple Range and Multiple F Tests. In "Biometrics", 11: 1-42

Düzgüneş, O. and E. Pekel 1966 Orta Anadolu Şartlarında Çeşitli Akkaraman X Merinos melezlerinin verimle ilgili özellikleri üzerinde mukayeseli Araştırmalar. T.B.T.A. Kurumu Proje No VHAG-6

Koncağül S., N. Akça, M. E. Vural, A. Karataş and M. Bingöl 2012 Zom Koyunlarınin Morfolojik Özellikleri (Morphological Characteristics of Zom Sheep). Kafkas Univ. Vet. Fak. Derg., 18: $829-837$

Minitab, 1998 Minitab Release 12.1 version for Windows, Minitab Inc.

Pekel, E. and O. Düzgüneş 1966 Malya devlet üretme çiftliğinde çeşitli merinos melezleri ile akkaraman kuzularında yaşama gücü ve gelişme. Ankara Üniv. Zir. Fak. Yıllı̆̆ı, 1-2: 62-80 